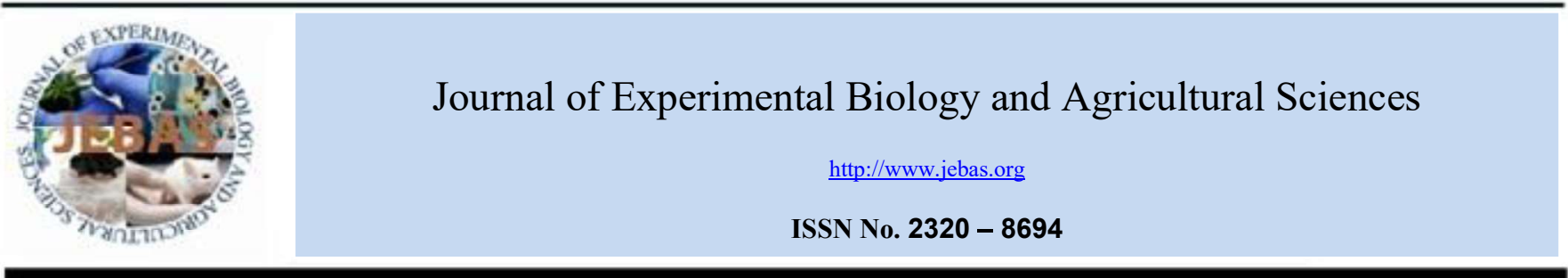

\title{
IDENTIFICATION OF SUPERIOR PARENTS AND CROSS COMBINATION FOR SEED YIELD AND ITS ATTRIBUTING TRAITS IN Brassica juncea
}

\author{
Aditi Eliza Tirkey*, Girish Tantuway, Kartikeya Srivastava \\ Department of Genetics and Plant Breeding, Institute of Agricultural Sciences, Banaras Hindu University, Varanasi -221005, Uttar Pradesh
}

Received - October 23, 2019; Revision - January 10, 2020; Accepted - January 14, 2020

Available Online - February 25, 2020

DOI: http://dx.doi.org/10.18006/2020.8(1).21.29

\section{KEYWORDS \\ Line $\mathrm{x}$ tester \\ GCA \\ SCA}

Heterosis

Indian mustard

\begin{abstract}
Current study was aimed to study the general combining ability (GCA) and specific combing ability (SCA) of 27 Indian mustard derived hybrids and estimation of average heterosis, heterobeltiosis and standard heterosis. Three testers namely Kranti, NRCHB101 and Vardan were crossed with nine lines and twenty seven hybrids were developed which were evaluated in completely randomized block design in the year 2017-18. Among various tested lines BPR 541-4 and RH 406 recorded positive and significant gca effects while among testers only NRCHB 101 have positive and significant gca effects for total seed yield per plot. Only NRCHB 101 recorded positive significant gca effects for seed yield (q/ha). Similarly, positive significant sca effect was exhibited by NRCHB 101 X PM 30 for seed yield (q/ha).. For seed yield per plant positive and significant average heterosis was found in four crosses with magnitude ranging from 23.01 to 67.87 while positive and significant heterobeltiosis was seen in NRCHB 101 X RH 406 and NRCHB 101 X Pusa Bold. Improvement methods which exploit both additive and non additive gene effects could be useful for the characters included in the present study.
\end{abstract}

* Corresponding author

E-mail: elizztirkey@gmail.com (Aditi Eliza Tirkey)

Peer review under responsibility of Journal of Experimental Biology and Agricultural Sciences.

Production and Hosting by Horizon Publisher India [HPI] (http://www.horizonpublisherindia.in/).

All rights reserved.
All the articles published by Journal of Experimental Biology and Agricultural Sciences are licensed under a Creative Commons Attribution-NonCommercial 4.0 International License Based on a work at www.jebas.org.

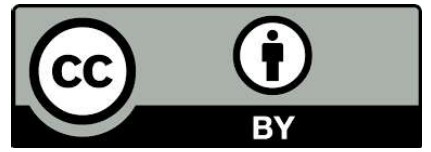




\section{Introduction}

Indian mustard is the major Rabi oilseed crop of India. Its production has increased steadily from $1304 \mathrm{~kg} / \mathrm{ha}$ in $2016-17$ to $1397 \mathrm{~kg} / \mathrm{ha}$ in 2017-18 through conventional and modern plant breeding methods but still this increase is not enough to meet demand of edible oilseed which is 254.16 lakh tonns (Annonymous, 2017) and India has to import edible oils. Rapeseed mustard is the second most important edible oilseed crop of India after groundnut sharing $27.8 \%$ in the India's oilseed economy. India is the largest rapeseed producing country in the world and occupying an area of 5.96 million ha with a production of 8.32 million tones and productivity of 13.95 quintal per ha. Therefore there is need to increase the production of oilseed in India and plant breeders need to focus on increasing seed yield. Seed yield is a quantitative character and has low heritability in most cases and is largely influenced by environment therefore achieving desired result is challenging for the breeders. The line $\mathrm{x}$ tester analysis helps in the recognition of good general combiners and specific cross combinations in addition to selection of breeding method for genetic improvement of several quantitative characters. In mustard breeding program, magnitude of general and specific combining ability are important indicators of the potential inbred lines in hybrid combinations hence useful in designing successful breeding scheme by developing hybrid and open pollinated varieties. The information on combining ability is important for selecting parent plants, understanding the nature of gene actions involved, introgressing elite traits and maximizing yield. Predominance effects of GCA on yield and most of the yield components indicating the importance of additive gene action is done by combining ability studies (Wos et al., 1999). Pandey et al. (1999) provided evidence for the presence of significant SCA effects for yield and yield components indicating importance of non-additive gene action in their review. The GCA variance includes additive part of total variance while SCA comprises non-additive portion of total variance that arises from dominance and epistatic deviations and by utilizing this information breeders can develop hybrids by selecting suitable parents (Reif et al., 2007). Previous studies have shown that significant GCA and SCA effects for yield and its component traits indicate that both additive and non-additive gene actions are important in the inheritance of traits (Meena et al., 2015). Selection of diverse parents with good general combining ability is very important in heterosis breeding since utilization of heterosis is the answer to maximum improvement in yield levels. Since different genetic materials exhibit different genetic parameters, the objective of the present study is to examine the combining ability patterns of selected Indian mustard genotypes in line $\mathrm{x}$ tester analysis and to determine superior cross combinations.

\section{Materials and Methods}

The experimental material comprised of nine lines viz., PM 25, PM 26,PM 30,RH 406, BPR 541-1, SEJ2, Urvashi, Giriraj and PusaBold along with three testers Kranti, Vardan and NRCHB101which were crossed in line $\mathrm{x}$ tester mating design. The resultant twenty seven hybrids along with their twelve parents and two checks (RH749, Hybrid Mustard 5222) were evaluated in compact family block design with three replications at agricultural research farm, Institute of Agricultural Sciences, Banaras Hindu University, Varanasi during Rabi, 2017-18. A sample of five representative plants was taken from each plot for recording the data on different traits viz. height of plant, number of silique per plant, number of seeds per silique, weight of 1000 seeds (g), seed yield per plant $(\mathrm{g})$, seed yield per plot $(\mathrm{kg})$ and seed yield ( $\mathrm{q} / \mathrm{ha}$ ) while days to $50 \%$ flowering and days to $75 \%$ maturity were recorded visually. The data pertaining to various characters were analyzed for combining ability for various traits as per method given by Kempthorne (1957). The heterosis (\%) was tested in comparison with mean value of two parents (average heterosis/AH), better parent (Heterobeltiosis/HB) and standard parent/check (standard heterosis) as per formulae $\mathrm{AH}=100 \mathrm{x}[(\mathrm{F} 1-\mathrm{MP}) / \mathrm{MP})]$ suggested by Briggle (1963), Fonseca \& Patterson (1968) suggested HB = $100 \mathrm{x}$ $[(\mathrm{F} 1-\mathrm{BP}) / \mathrm{BP})]$ and $\mathrm{SH}=100 \times[(\mathrm{F} 1-\mathrm{SP}) / \mathrm{SP})]$ suggested by Meredith \& Bridge (1972) respectively. Where $\mathrm{F} 1=$ mean of Hybrid Performance, $\mathrm{BP}=$ Mean of better parents and $\mathrm{SP}=$ Mean of Standard parent/ check.

\section{Results and Discussion}

The mean sums of square for nine quantitative characters are presented in Table 1. The mean sum of squares for treatments were found to be significant for all traits suggesting significant variability among all the treatments i.e. sufficient variability existed among parents and crosses. Highly significant differences among the treatments for characters namely, days to $50 \%$ flowering, days to maturity, plant height, number of siliqua per plant, number of seeds per siliqua, 1000 seed weight and seed yield per plant was also reported by Chaurasiya et al.(2018). The mean sum of square for parents showed significant differences indicating sufficient variability among parents for all traits except plant height while the variances due to lines showed significant differences for maximum traits except plant height, suggesting existence of sufficient genetic variability. Similarly, the testers showed significant variability for most of the traits except plant height and seed yield per plant. The mean sum of square was significant for days to $50 \%$ flowering, days to $75 \%$ maturity, 1000 seed weight and seed yield per plant for lines vs testers. Highly significant differences for all the studied characters were exhibited by hybrids. Parents $v$ hybrids as indicator of average heterosis also showed significant differences for all traits except plant height indicating of superiority of crosses over parents. These results were also similar to Kumar et al.(2017) and Vaghela et al. (2011).

The analysis of variance for combining ability with respect of studied nine characters indicated that mean sum of squares due to line $\mathrm{X}$ tester interaction were highly significant for seeds per silique, test weight, seed yield per plant, seed yield per plot, seed yield (Table 2). The sca 


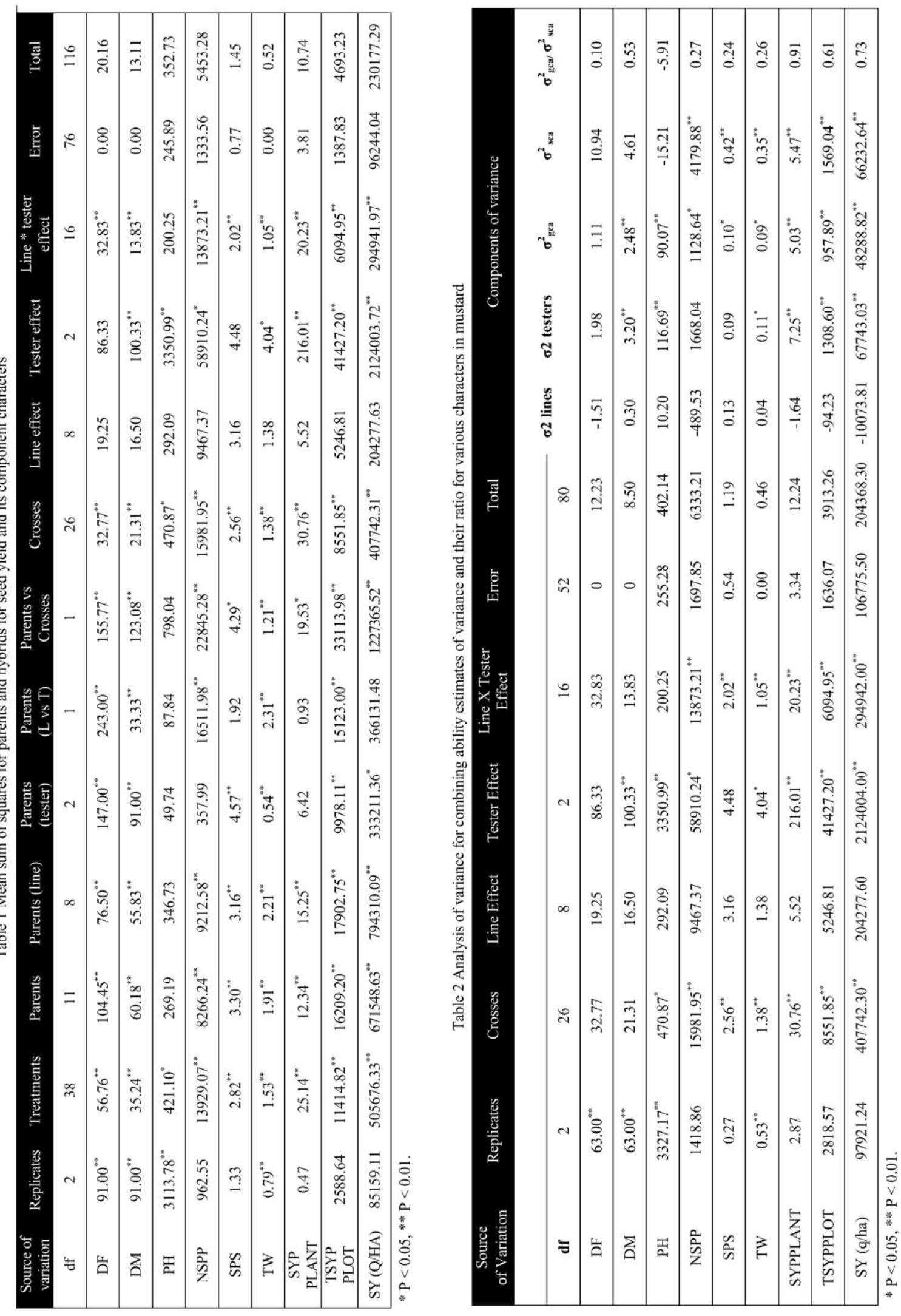

Journal of Experimental Biology and Agricultural Sciences http://www.jebas.org 
variance was found to be higher than the gca variance - for days to $50 \%$ flowering, days to $75 \%$ maturity, plant height, number of silique per plant, seeds per siliqua and test weight, seed yield per plant, seed yield per plot and seed yield ( $\mathrm{q} / \mathrm{ha})$ i.e. variance ratio was less than unity for the traits indicating predominance of dominance variance which indicated greater contribution of females towards gca variance for these traits. In present study, contribution of females for variability was found to be higher than that of males for most of the traits therefore, dominance variance was more than additive variance for all characters studied. Thus, for the improvement of these traits, biparental mating and recurrent selection is advocated. These results are in accordance with the findings of Kumar et al.(2017), Singh \& Ranjeet (2010) and Sagwal \& Rana (2010) in case of test weight, seed yield per plant, number of siliquae per plant and flowering days respectively.

The estimates of gca effects of parents are presented in Table 3. Among lines for days to $50 \%$ flowering significant gca effect in positive direction was exhibited by BPR 541-1 (2.33), Giriraj (1.33), PM 26 (0.67) and Pusa Bold (0.67) while among testers only NRCHB 101 (1.89) showed significant positive gca effect. Among lines Giriraj (2.11), RH 406 (1.44), PM 25 (1.11) and Sej 2(0.44) while among testers only Vardan (2.11) showed significant positive gca for days to maturity. For number of silique per plant significant gca effect in positive direction among lines were observed in BPR 541-4 (44.24) followed by PM 30 (35.70) and PM 26 (34.42). Similarly among the testers Vardan (27.47) recorded higher significant positive gca effect followed by NRCHB 101 (26.46) while for number of seeds per silique RH 406 (0.92) showed positive gca effect and none of the testers showed positive gca effect. Urvashi (0.54) showed highest significant gca effect for test weight followed by Pusa bold (0.36) and BPR 541-4 (0.21). Similarly among testers Kranti (0.35) and Vardan (0.07) recorded positive significant gca effect for test weight. For seed yield per plant none of the lines have significant GCA effects but NRCHB 101 (2.96) has positive significant GCA effect among tester. For total seed yield per plot BPR 541-4 (44.84) and RH 406 (27.62) have positive significant GCA effects while among testers only NRCHB 101(44.51) was found to have positive and significant GCA effects. Only NRCHB 101 among testers recorded positive significant GCA effects (312.80) for seed yield ( $\mathrm{q} / \mathrm{ha})$. Similar finding was also reported by Singh et al. (2010). The estimates of SCA effects in 27 hybrid combinations for nine quantitative traits were presented in the table 4. All the crosses were found to be significant for days to $50 \%$ flowering, days to maturity and test weight. Four out of twenty seven crosses exhibited positive significant SCA effects for number of silique per plant, hybrid Vardan x PM 30 (141.90) showed highest positive significant SCA effect which was followed by NRCHB 101 x BPR 541-4 (116.05) and Vardan x PM 25 (73.33). None of the hybrids showed significant sca effects for seeds per silique. Among hybrids only Sixteen of them showed positive significant SCA effects for test weight. Positive significant SCA effect for seed yield per plant was exhibited only by one hybrid NRCHB 101 X RH 406 (5.67). For total seed yield per plot hybrid NRCHB 101 X PM 30 (75.05) showed highest positive significant SCA effect followed by

Table 3 The estimates of General combining ability (gca) effect of the parents for various characters in mustard.

\begin{tabular}{|c|c|c|c|c|c|c|c|c|c|}
\hline Lines & $\mathrm{DF}$ & $\mathrm{DM}$ & PH & NSPP & SPS & TW & SYPPLANT & TSYPPLOT & SY (q/ha) \\
\hline PM-25 & 0 & $1.11^{* *}$ & -7.9 & 9.15 & $-0.73^{*}$ & $-0.22^{* *}$ & -1.13 & $-26.83^{*}$ & -197.22 \\
\hline PM-26 & $0.67^{* *}$ & $-1.56^{* *}$ & -4.5 & $34.42^{* *}$ & 0.25 & $-0.82^{* *}$ & -0.1 & -0.94 & 21.29 \\
\hline PM-30 & $-0.67^{* *}$ & $-1.22^{* *}$ & 2.7 & $35.70^{* *}$ & -0.08 & $-0.07^{* *}$ & -0.39 & $-25.16^{*}$ & -164 \\
\hline RH- 406 & $-1.00^{* *}$ & $1.44^{* *}$ & 9.16 & -0.87 & $0.92^{* *}$ & $-0.06^{* *}$ & 1.16 & $27.62^{*}$ & 160.4 \\
\hline BPR-541-1 & $2.33^{* *}$ & $-0.22^{* *}$ & 5.58 & $44.24^{* *}$ & $-0.77^{*}$ & $0.21^{* *}$ & 0.07 & $44.84^{* *}$ & 204.7 \\
\hline SEJ-2 & $-2.67^{* *}$ & $0.44^{* *}$ & -4.99 & $-27.52^{*}$ & 0.32 & $0.16^{* *}$ & -0.46 & -16.72 & -141.21 \\
\hline URVASHI & $-0.67^{* *}$ & $-0.56^{* *}$ & -4.46 & $-40.23^{* *}$ & $-0.64^{*}$ & $0.54^{* *}$ & -0.73 & -0.38 & 5.02 \\
\hline GIRIRAJ & $1.33^{* *}$ & $2.11^{* *}$ & 2.32 & -23.36 & 0.41 & $-0.10^{* *}$ & 1.05 & -12.49 & -48.36 \\
\hline PUSA-BOLD & $0.67^{* *}$ & $-1.56^{* *}$ & 2.1 & $-31.52^{*}$ & 0.32 & $0.36^{* *}$ & 0.52 & 10.06 & 159.37 \\
\hline Minumum & -2.67 & -1.56 & -7.9 & -40.23 & -0.77 & -0.82 & -1.13 & -26.83 & -197.22 \\
\hline Maximum & 2.33 & 2.11 & 9.16 & 44.24 & 0.92 & 0.54 & 1.16 & 44.84 & 204.7 \\
\hline $\mathrm{P}$ value $(\mathrm{P}<0.05)$ & 0.78 & 0.36 & 0.25 & 0.70 & 0.21 & 0.30 & 0.97 & 0.56 & 0.69 \\
\hline \multicolumn{10}{|l|}{ Testers } \\
\hline Kranti & $-0.22^{* *}$ & $-1.67^{* *}$ & -0.32 & $-53.93^{* *}$ & 0.14 & $0.35^{* *}$ & $-2.68^{* *}$ & $-15.27^{*}$ & -83.71 \\
\hline Vardan & $-1.67^{* *}$ & $2.11^{* *}$ & $-10.98^{* *}$ & $27.47^{* *}$ & $-0.46^{* *}$ & $0.07^{* *}$ & -0.27 & $-29.24^{* *}$ & $-229.09^{* *}$ \\
\hline NRCHB-101 & $1.89^{* *}$ & $-0.44^{* *}$ & $11.30^{* *}$ & $26.46^{* *}$ & 0.32 & $-0.42^{* *}$ & $2.96^{* *}$ & $44.51^{* *}$ & $312.80^{* *}$ \\
\hline Minumum & -1.67 & -1.67 & -10.98 & -53.93 & -0.46 & -0.42 & -2.68 & -29.24 & -229.09 \\
\hline Maximum & 1.89 & 2.11 & 11.3 & 27.47 & 0.32 & 0.35 & 2.96 & 44.51 & 312.8 \\
\hline $\mathrm{P}$ value $\mathrm{P}<0.05$ & 0.10 & 0.01 & 0.00 & 0.03 & 0.14 & 0.04 & 0.00 & 0.00 & 0.00 \\
\hline
\end{tabular}

Journal of Experimental Biology and Agricultural Sciences

http://www.jebas.org 
Table 4 The estimates of Specific combining ability (sca) effect of the crosses for various characters in mustard.

\begin{tabular}{|c|c|c|c|c|c|c|c|c|c|}
\hline Crosses & DF & $\mathrm{DM}$ & PH & NSPP & SPS & TW & $\begin{array}{l}\text { SYP } \\
\text { PLANT }\end{array}$ & $\begin{array}{l}\text { TSYP } \\
\text { PLOT }\end{array}$ & $\mathrm{SY}(\mathrm{Q} / \mathrm{HA})$ \\
\hline KRANTI X PM 25 & $-0.78^{* *}$ & $-1.33^{* *}$ & -1.04 & $-42.40^{*}$ & -0.10 & $0.37^{* *}$ & -1.27 & 8.83 & 18.48 \\
\hline VARDAN X PM25 & $-2.33^{* *}$ & $-1.11^{* *}$ & 0.35 & $73.33^{* *}$ & -0.43 & $0.06^{* *}$ & 0.05 & 42.79 & 301.38 \\
\hline NRCHB101 X PM25 & $3.11^{* *}$ & $2.44^{* *}$ & 0.68 & -30.93 & 0.53 & $-0.43^{* *}$ & 1.22 & $-51.62^{*}$ & -319.87 \\
\hline KRANTI X PM26 & $-1.44^{* *}$ & $1.33^{* *}$ & 1.17 & -15.00 & -0.67 & $-0.18^{* *}$ & 1.37 & 33.27 & 300.99 \\
\hline VARDAN X PM26 & $1.00^{* *}$ & $-1.44^{* *}$ & -1.45 & 2.33 & 0.26 & $-0.59^{* *}$ & 1.76 & -8.10 & -14.90 \\
\hline NRCHB 101 X PM26 & $0.44^{* *}$ & $0.11^{* *}$ & 0.28 & 12.67 & 0.42 & $0.78^{* *}$ & $-3.13^{* *}$ & -25.17 & -286.10 \\
\hline KRANTI X PM30 & $0.89^{* *}$ & $-1.00^{* *}$ & -1.97 & $-65.02^{* *}$ & -0.07 & $0.11^{* *}$ & 1.33 & -21.84 & -200.96 \\
\hline VARDAN X PM30 & $0.33^{* *}$ & $1.22^{* *}$ & -1.11 & $141.90^{* *}$ & -0.94 & $-0.64^{* *}$ & -1.62 & $-53.21^{*}$ & $-391.75^{*}$ \\
\hline NRCHB101 X PM30 & $-1.22^{* *}$ & $-0.22^{* *}$ & 3.08 & $-76.88^{* *}$ & 1.02 & $0.53^{* *}$ & 0.29 & $75.05^{* *}$ & $592.71^{* *}$ \\
\hline KRANTI X RH406 & $1.22^{* *}$ & $1.33^{* *}$ & -4.04 & 37.49 & 0.93 & $-0.69^{* *}$ & -1.83 & 0.05 & 46.37 \\
\hline VARDAN X RH 406 & $2.67^{* *}$ & $-2.44^{* *}$ & -11.58 & $-44.92^{* *}$ & 0.13 & $0.35^{* *}$ & $-3.84^{* *}$ & -4.99 & -65.09 \\
\hline NRCHB101 X RH406 & $-3.89^{* *}$ & $1.11^{* *}$ & 15.61 & 7.43 & $-1.05^{*}$ & $0.34^{* *}$ & $5.67^{* *}$ & 4.94 & 18.72 \\
\hline KRANTI X BPR 541-4 & $-3.11^{* *}$ & $3.00^{* *}$ & 14.85 & -17.69 & $-1.05^{*}$ & $0.06^{* *}$ & 0.86 & $65.16^{* *}$ & 306.37 \\
\hline VARDAN X BPR541-4 & $-0.67^{* *}$ & $-1.78^{* *}$ & -4.32 & $-98.36^{* *}$ & 0.68 & $-0.32^{* *}$ & 0.32 & -10.88 & 36.20 \\
\hline NRCHB101 X BPR541-4 & $3.78^{* *}$ & $-1.22^{* *}$ & -10.53 & $116.05^{* *}$ & 0.37 & $0.26^{* *}$ & -1.18 & $-54.28^{*}$ & -342.57 \\
\hline KRANTI X SEJ2 & $-0.11^{* *}$ & $-3.67^{* *}$ & 0.52 & $63.53^{* *}$ & -0.27 & $0.25^{* *}$ & 1.86 & 3.72 & 101.77 \\
\hline VARDAN X SEJ2 & $-0.67^{* *}$ & $2.56^{* *}$ & 1.58 & -26.34 & -0.54 & $-0.52^{* *}$ & 1.32 & -2.65 & -94.27 \\
\hline NRCHB 101 X SEJ2 & $0.78^{* *}$ & $1.11^{* *}$ & -2.10 & -37.19 & 0.82 & $0.27^{* *}$ & $-3.18^{* *}$ & -1.06 & -7.50 \\
\hline KRANTI X URAVSHI & $-3.11^{* *}$ & $1.33^{* *}$ & -6.68 & 7.58 & 0.88 & $0.08^{* *}$ & 0.99 & 3.05 & 34.47 \\
\hline VARDAN X URVASHI & $0.33^{* *}$ & $-0.44^{* *}$ & 1.78 & -21.43 & -0.19 & $0.49^{* *}$ & -0.62 & 22.35 & 172.57 \\
\hline NRCHB101 X URVASHI & $2.78^{* *}$ & $-0.89^{* *}$ & 4.90 & 13.85 & -0.70 & $-0.57^{* *}$ & -0.38 & -25.40 & -207.04 \\
\hline KRANTI X GIRIRAJ & $-0.11^{* *}$ & $-0.33^{* *}$ & -2.32 & 27.18 & 0.24 & $0.08^{* *}$ & -0.12 & -25.51 & -250.38 \\
\hline VARDAN x GIRIRAJ & $-0.67^{* *}$ & $0.89^{* *}$ & 4.73 & -25.76 & 0.64 & $0.82^{* *}$ & 0.74 & -1.54 & -23.89 \\
\hline NRCHB101 X GIRIRAJ & $0.78^{* *}$ & $-0.56^{* *}$ & -2.41 & -1.42 & -0.87 & $-0.90^{* *}$ & -0.62 & 27.05 & 274.28 \\
\hline KRANTI X PUSA BOLD & $6.56^{* *}$ & $-0.67^{* *}$ & -0.50 & 4.33 & 0.13 & $-0.07^{* *}$ & $-3.19^{* *}$ & $-66.73^{* *}$ & -357.11 \\
\hline VARDAN X PUSA BOLD & & $2.56^{* *}$ & 10.02 & -0.74 & 0.39 & $0.35^{* *}$ & 1.87 & 16.24 & 79.75 \\
\hline NRCHB101 X PUSA BOLD & $-6.56^{* *}$ & $-1.89^{* *}$ & -9.52 & -3.59 & -0.52 & $-0.28^{* *}$ & 1.31 & $50.49^{*}$ & 277.36 \\
\hline $\mathrm{P}$ value $(\mathrm{P}<0.05)$ & 0.50 & 0.50 & 0.70 & 0.00 & 0.00 & 0.00 & 0.00 & 0.00 & 0.00 \\
\hline
\end{tabular}

Kranti X BPR 541-4 (65.16) and NRCHB 101 X Pusa Bold (50.49). For seed yield (q/ha) NRCHB 101 X PM 30 (592.71) showed positive significant sca effect. Similar results were found by Kumar et al. (2017), Gupta et al. (2010), Kaur et al. (2019) and Singh et al. (2010).

For a successful exploitation of heterosis in a breeding programme there must be evidence of the presence of significant heterotic effect in the hybrids along with connivance of commercial hybrid seed production. The extent of heterosis among twenty seven crosses for days to $50 \%$ flowering were presented in Table 5 . Out of 27 crosses, 13 crosses exhibited significant average heterosis in negative direction (desirable) with magnitude ranging from -0.91 to -19.19 in addition 24 crosses showed significant heterobeltios is in negative direction and values ranged from -1.81 to -21.91 . Vardan $\mathrm{x}$ Sej 2 (-1.45) showed significant negative standard heterosis (SH1) for this trait while 22 cross combinations showed significant negative standard heterosis with $\mathrm{m}$ agnitude ranging from -0.7 to -43.66 . Heterosis among twenty seven cross combinations for days to $75 \%$ maturity were presented in Table 5. Out of 27 crosses, nine crosses exhibited significant average heterosis in negative direction (desirable) with magnitude ranging from -0.38 to -3.07 in addition 15 crosses showed significant heterobeltiosis in negative direction and values ranged from 0.76 to -5.33 . Twenty three crosses out of 27 eveluated showed significant negative standard heterosis (SH1) with values ranging from -0.51 to -5.85 for days to $75 \%$ maturity while twenty five crosses showed significant negative standard heterosis ( $\mathrm{SH} 2)$ with magnitude ranging from (-0.76 to -6.8). For plant height (Table 5) 19 crosses showed significant average heterosis in negative direction with magnitude ranging from -1.14 to 12.39 while significant negative heterobeltiosis ranged from -1.04 to 14.09. Twelve crosses exhibited significant standard heterosis in negative direction over check RH 749 and values ranged from -0.15 to -7.77 on the other hand none of the crosses were found to show significant negative standard heterosis over hybrid mustard 5222. For number of silique per plant (Table 6) significant average heterosis and 


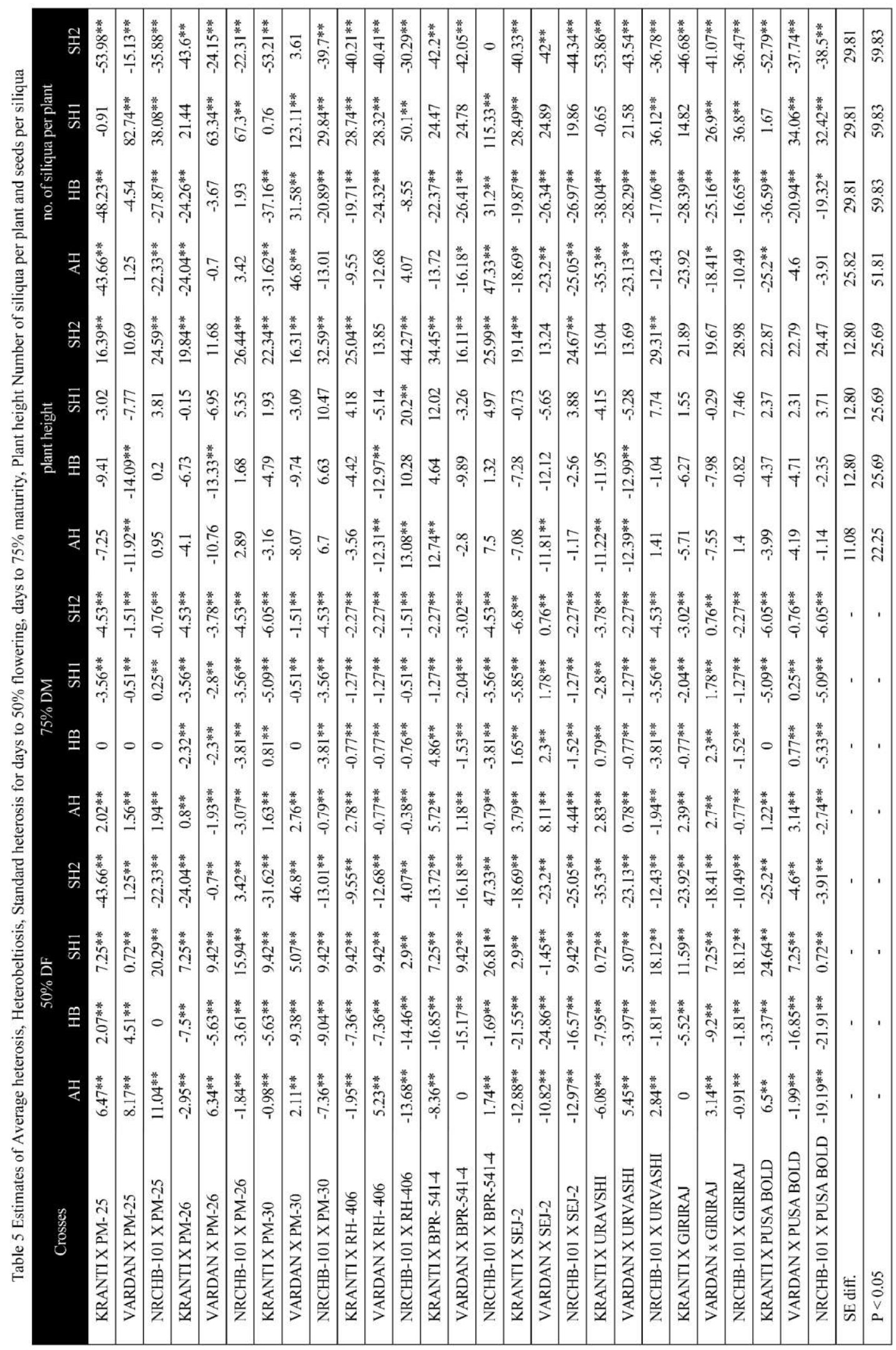

Journal of Experimental Biology and Agricultural Sciences http://www.jebas.org 


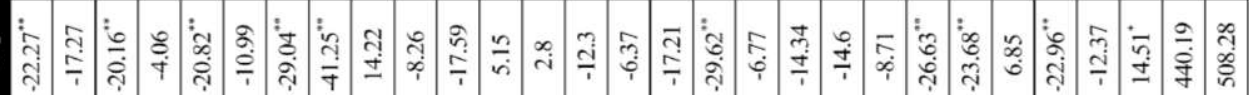

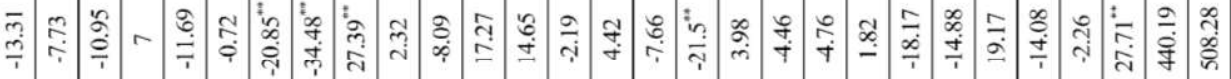

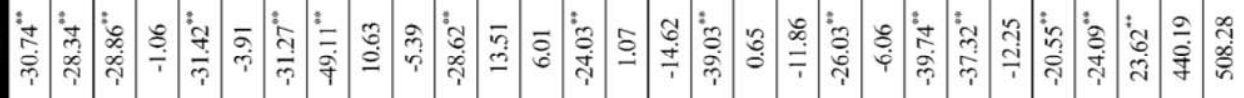

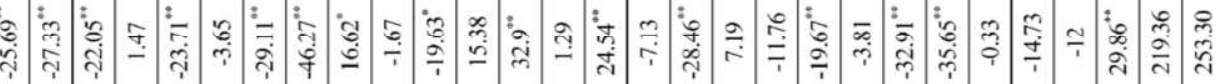

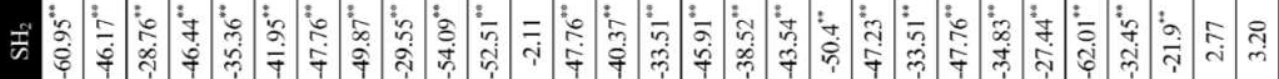
这。

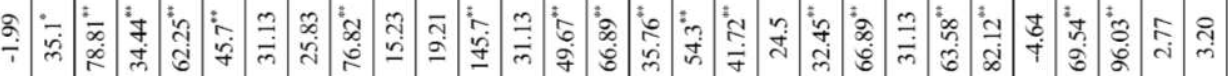

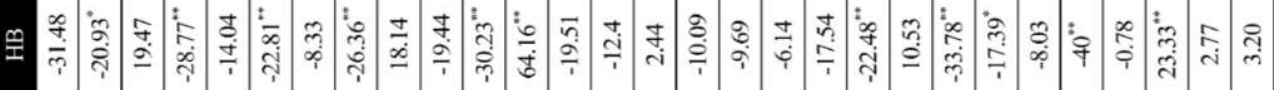

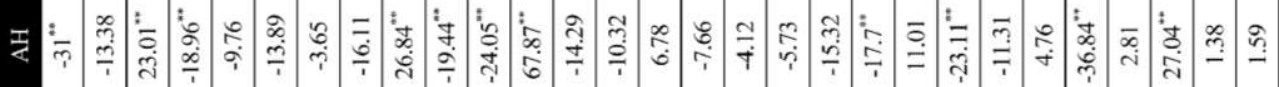

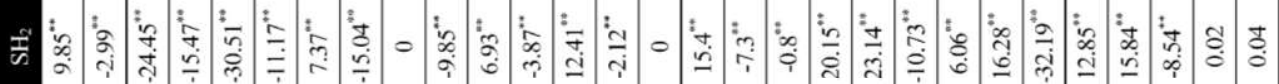

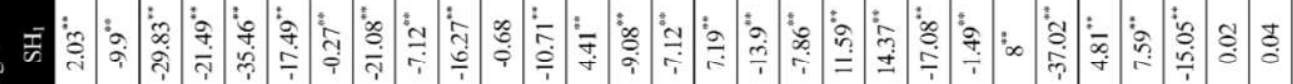

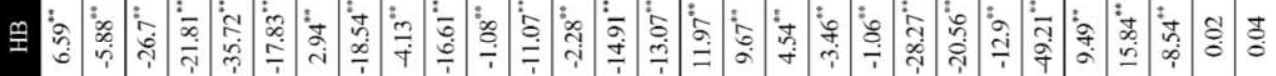

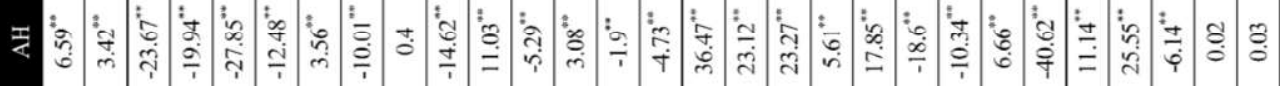

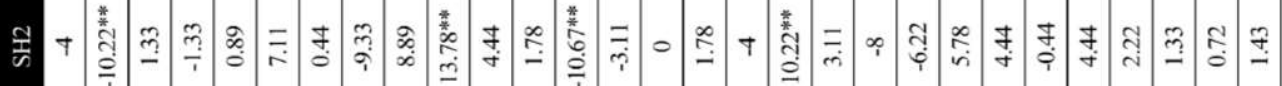

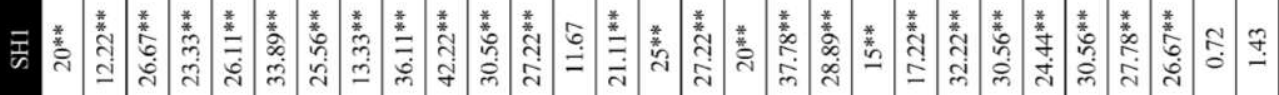

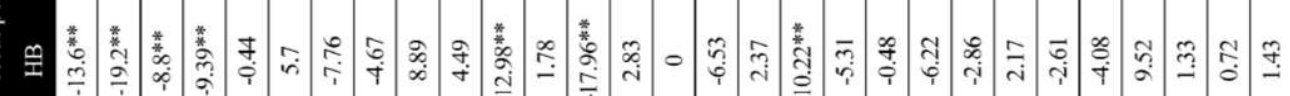

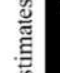

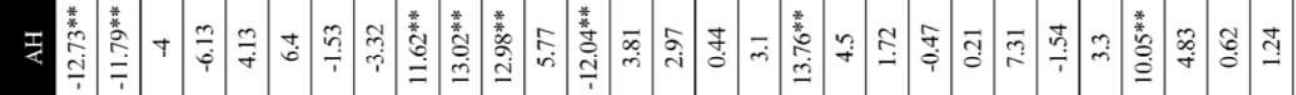
3.

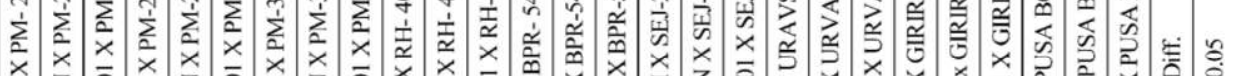

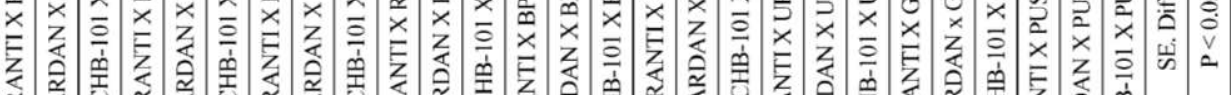

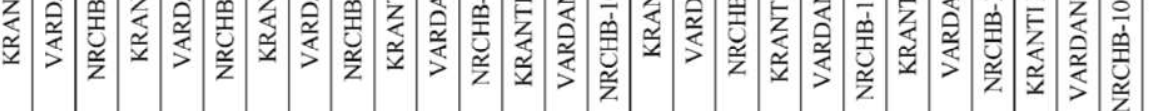

Journal of Experimental Biology and Agricultural Sciences http://www.jebas.org 
heterobeltiosis in positive direction was observed in Vardan $\mathrm{X}$ PM 30 and NRCHB 101 X BPR 541-4 with magnitude of 46.8 and 47.33 respectively for average heterosis and 31.58 and 31.2 respectively for heterobeltiosis. Sixteen hybrids showed significant positive heterosis over check RH 749 with values ranging from 26.9 to 123.11 while none of the cross combinations showed significant positive standard heterosis over check hybrid mustard 5222. Five crosses showed significant average heterosis in positive direction for number of seeds per silique with values ranging from 10.05 to 13.76 while only two crosses, Vardan X RH 406 (12.98) NRCHB 101 x Sej 2 (10.22) showed positive and significant heterobeltiosis almost all the crosses were found to have significant standard heterosis over check RH 749. Crosses Kranti X RH 406 (13.78) and NRCHB 101 X Sej 2 (10.22) exhibited significant positive standard heterosis over check hybrid mustard 5222. For test weight (Table 6) significant average heterosis was exhibited by thirteen hybrids with magnitude ranging from 3.08 to 36.47 while seven crosses showed significant positive heterobeltiosis with values ranging from 4.54 to 15.84 . Significant positive standard heterosis over check RH 749 was exhibited by five crosses with values ranging from 2.03 to 14.37 while positive significant standard heterosis over check hybrid mustard 5222 was found in ten crosses and values ranged from 6.06 to 23.14 . For seed yield per plant (Table 6) positive significant average heterosis was found in four crosses with magnitude ranging from 23.01 to 67.87 while positive and significant heterobeltiosis was seen in NRCHB 101 X RH 406 (64.16) and NRCHB 101 X Pusa Bold (23.33). Eighteen crosses with magnitude ranging from 32.45 to 145.7 showed significant standard heterosis over check RH 749 while none of the crosses showed heterosis over check hybrid mustard 5222. Seed yield per plot of four hybrids showed positive and significant average heterosis with magnitude ranging from 16.62 to 32.9 while only NRCHB 101 X Pusa Bold (23.62) showed significant heterobeltiosis. Standard heterosis over check RH 749 was exhibited by NRCHB 101 X PM 30 (27.39) and NRCHB $101 \mathrm{X}$ Pusa Bold (27.71) for seed yield per plot (Table 6) while only NRCHB 101 X Pusa Bold (14.51) showed significant heterosis over check hybrid mustard 5222 for seed yield per plot. Similar findings were also observed by Kaur et al. (2019), and Singh et al. (2010).

\section{Conclusion}

Analysis of variance for the compact family block design indicated that the mean sum of squares due to genotypes, parents, crosses and parents vs crosses which is an indicator of average heterosis were significant for all the characters studied. Only NRCHB101 X Pusa Bold and NRCHB101 X PM30 hybrids were found superior for seed yield per plot. For total seed yield per plot parental lines viz. BPR 541-4, RH406 and NRCHB101 were found to be good general combiners while hybrids NRCHB 101 X PM30, Kranti X BPR541-4 and NRCHB101 X Pusa Bold were found to have good specific combining ability.

\section{Acknowledgement}

Author expresses her sincere gratitude to the Department of Genetics and Plant Breeding, Institute of Agricultural Sciences, Banaras Hindu University, Varanasi and UGC for providing U.G.C. Research Fellowship for Ph.D in Genetics and Plant Breeding.

\section{Conflict of Interest}

Authors would hereby like to declare that there is no conflict of interests that could possibly arise.

\section{References}

Annonymous (2017) Pocket Book of agricultural statistics 2017.Directorate of Economics \& Statistics, Department of Agriculture, Cooperation \& Farmers Welfare, Ministry of Agriculture \& Farmers Welfare, Government of India. Pp.31-34.

Briggle LW (1963) Heterosis in wheat - a review. Crop Sciences 3: 407-412.

Chaurasiya JP, Singh M, Yadav RK, Singh L (2018) Hetrosis and combining ability analysis in Indian mustard (Brassica juncea $(\mathrm{L}$.$) Czern and Coss.). Journal of Pharmacognosy and$ Phytochemistry 7: 604-609.

Fonseca S, Patterson F (1968) Hybrid vigour in a seven parent diallel crosses in common winter wheat (Triticum aestivum L.). Crop Sciences $8: 85-88$.

Gupta P, Chaudhary HB, Lal SK (2010) Heterosis and combining ability analysis for yield and its components in Indian mustard [Brassica juncea (L.)Czern and Coss)]. Frontiers of Agriculture in China 4:299-307.

Kaur S, Kumar R, Kaur R, Singh I, Singh H, Kumar V (2019) Heterosis and combining ability analysis in Indian mustard (Brassica juncea L.). Journal of Oilseed Brassica 10:38-46.

Kempthorne O (1957) An Introduction to Genetic Statistics. John Wiley and Sons, New York.

Kumar R, Sing M, Tomar A (2017) Combining ability (gca\&sca) and heterotic response analysis in Indian mustard (Brassica juncea L. Czern\&Coss). International Journal of Applied Research 3: 719-724.

Meena HS, Kumar A, Ram B, Singh VV, Meena PD, Singh BK, Singh D (2015) Combining Ability and Heterosis for Seed Yield and Its Components in Indian Mustard (Brassica junceaL.). Journal of Agricultural Sciences and Technology 17: 1861-1871.

Meredith WR, Bridge RR (1972)Heterosis and gene action in cotton Gossypiumhirsutum. Crop Sciences 12:304-310. 
Pandey LD, Singh B, Sachan JN (1999) Brassica hybrid research in India. Status and Prospects Paper Pp. 263.

Reif JC, Gumpert FM, Fischer S, Melchinger AE (2007) Impact of interpopulation divergence on additive and dominance variance in hybrid populations. Genetics 176: 1931-1934

Sagwal TC, Rana SK (2010) Heterosis and combining ability in rapeseed [Brassica napus (L.)]. International Journal of Agricultural Sciences 15: 163-167.

Singh SP, Ranjeet (2010) Genetics of yield components and oil content in Indian mustard. International Journal of Plant Sciences 5: 60-66.
Singh M, Singh L, Srivastava SBL (2010) Combining ability analysis in Indian mustard [Brassica juncea (L.) Czern and Coss]. Journal of oilseed Brassica 1:23-27.

Vaghela PO, Thakkar DA, Bhadauria HS,Sutariya DA, Parmar SK Prajapati, DV (2011) Heterosis and combining ability for yield and its component traits in Indian mustard (Brassica juncea (L.)Czern and Coss). Journal of Oilseeds Research 2:39-43.

Wos H, Bartkowiak-Broda I, Budzianowski G, Krzymanski J (1999) Breeding of Winter and Spring Oilseed Rape Hybrids at Malyszyn: Paper 544. In: "Proceeding of 10th International Rapeseed Conference [CD-ROM], Canberra, Australia. Pp: 26-29. 